-RESEARCH PAPER-

\title{
COMMUNICATIVE PLANNING AND PARTICIPATION IN SWEDEN THROUGH PLANNER'S PERSPECTIVE: CASE OF ULLERÅKER REGION
}

\author{
Pınar AKARÇAY ${ }^{1}$
}

\begin{abstract}
The communicative planning approach that has come to the fore in the urban planning literature in the last decades has changed both the urban planning processes and the position and role of the planners. The concept of communicative planning, which carries traditional and hierarchical planning processes to a communicative base by developing dialogue and cooperation between participants/actors, has brought planners beyond being a simple bureaucrat/technocrat as well. This study problematizes how planners perceive and implement the roles of communicative planning for planners. In this problematic context, in this study, which selected Ulleråker urban planning project in Uppsala, Sweden as a case study, face-to-face semi-structured interview data with 13 planners who worked in Ulleråker project were analyzed.
\end{abstract}

Keywords: Communicative Planning, Citizen Participation, Role of Planners, Ulleråker, Sweden.

JEL Codes: N90, O21, R58, Z18.

Başvuru: 03.02.2020 Kabul: 16.05 .2020

1 Dr.Öğr. Üyesi Trakya Üniversitesi, Edirne, Türkiye, pinarakarcay@trakya.edu.tr , ORCID 0000-0002-52310567 


\section{PLANLAMACILARIN PRESPEKTIFINDEN İSVEÇ'TE ILLETIŞIMSEL PLANLAMA VE KATILIMCILIK: ULLERÅKER BÖLGESİ ÖRNEĞİ}

$\ddot{O} z$

Son yıllarda kent planlama literatüründe öne çıkan iletişimsel (communicative) planlama yaklaşımı, hem kentsel planlama süreçlerini hem de planlamacıların konumunu ve rolünü değiştirmiştir. Geleneksel ve hiyerarşik planlama süreçlerini, katılımcılar/aktörler arası diyalog ve işbirliği geliştirerek iletişimsel bir tabana taşıyan iletişimsel planlama anlayışı, planlamacıları da basit bir bürokrat/teknokrat olmanın ötesine taşımıştır. Bu çalışmanın sorunsalı, iletişimsel planlamanın planlamacılar için ortaya koyduğu rollerin ve uygulanışının planlamacılar tarafindan nasıl algılandığıdır. Bu sorunsal doğrultusunda, İsveç’in Uppsala kentinde yer alan Ulleråker kentsel planlama projesini örnek olay olarak seçen bu çalışmada, Ulleråker projesinde çalışmış 13 planlamacıyla yapılmış yüz yüze yarı yapılandırılmış mülakat verileri analiz edilmiştir.

Anahtar Kelimeler: İletişimsel Planlama, Vatandaş Katılımı, Planlamacıların Rolü, Ulleråker, İsveç.

JEL Kodları: N90, O21, R58, Z18.

'Bu çalışma Araştırma ve Yayın Etiğine uygun olarak hazırlanmıştır.'

\section{INTRODUCTION}

Communicative planning was first suggested by Habermas (1984) as communicative rationality and then developed by Dryzek (1990) for policymaking processes and adopted to planning processes by Forester (1989), Sager (1994) and Innes (1995) (Innes, 1996). Communicative rationality was based on the communication between the participants/actors in the planning processes, deliberation, and consensus. Since 1980s, several planning theories were started to be developed based on deliberation and consensus. Communicative planning which is called as collaborative planning in British literature (Healey, 1997) and deliberative planning in American literature (Forester, 1999), gained a dominant place in the urban planning literature by paving the way for planning theories such as argumentative planning (Fisher and Forester, 1993) and participatory planning (Forester, 1999) (Allmendinger and Tewdwr-Jones, 2002). Thus, after a definition and theory-crafting process of communicative planning for approximately 40 years with various descriptions, new communicative processes and roles were developed that are based on common sense, deliberation, consensus, and cooperation instead of a traditional, hierarchical and bureaucratic planning approach that control 
planning processes (Mazza, 1995). In this context, the issue of who would provide common sense, deliberation, consensus and cooperation and how these concepts would be provided has been the focus of communicative planning discussions (Fox-Rogers and Murphy, 2015).

In addition to its difficult answer, most of the responsibility was given to the planners in the communicative planning approach. Therefore, planners took on a task of making the citizens strong and efficient in the planning processes and basing the planning processes on a deliberative and conciliatory ground by extending across the traditional bureaucrat/technocrat roles and sharing the traditional political and elitist powers. In this sense, the primary objectives of planners are having common sense, informing and listening to people and enabling consensus between the different opinions and reflecting the outcomes of this consensus to the plans (Fainstein, 2000).

On the other hand, how much the planners diverge from their traditional bureaucratic roles and traditional planning approach and how successful they can create a consensus has long been an issue of discussion (Mazza, 1995). Thus, although there are several studies in the urban planning literature focused on the new roles of planners whose traditional roles are changing, however there are scarcely any studies that examine how do the planners perceive and apply this new role from their perspective. Therefore, the main purpose of this study is to reveal how planners perceive the roles that communicative theories attribute to them and how do they apply these roles from their point of view. In this context, answers were sought for the following questions:

- How do the planners perceive the roles that communicative planning attribute to them?

- How do the planners perceive application of the roles that communicative planning attributes to them?

Answers were produced to these questions regarding the urban planning project examination of Ulleråker region which is located in Uppsala, the fourth biggest city of Sweden. Since Sweden is one of the countries that took legal and administrative steps towards the development of planning processes based on communication and dialog between the local governments and other participants/ actors (see Listerborn, 2007; Lijphart, 1999; Danielsson et al., 2018 for detailed information), it was preferred in accordance with the problematic and purpose of this study. The Ulleråker project was chosen as a case for this study since it is a project that would affect not only the future of Ulleråker region but also the city of Uppsala due to the fact that it is the biggest urban project in the city of Uppsala with 7000 new structures. 


\subsection{Literature Review}

\subsubsection{The Meaning of Communicative Planning and The Changing Role of The Planners}

In the traditional planning approach, planners who are known as bureaucrats guided by the local political representatives, are perceived as the professionals who have technical knowledge and expertise on planning and subsidiaries of the political and top-down hierarchical system (Beckman, 1964). In the traditional planning logic, planners conducted the role of supporting the elected local representatives, who are decision-making authorities that are responsible for creating harmony between several political and administrative elements, with their knowledge and expertise in the planning processes (Beckman, 1964). Thus, in the traditional planning approach, planners were identified within the hierarchical and bureaucratic planning processes that include the guidance and political concerns of elected representatives. Communicative planning logic, on the other hand, was based on the communication and interaction between the participants and actors beyond the hierarchical and bureaucratic logic of the traditional planning approach (See Table 1).

Communicative rationality was first discussed by Habermas (1984) as the criticism of the system which put forwards unequal power relations between the governing and governed with bureaucratic roles and legal-executive regulations. The basic communicative rationality that was introduced by Habermas was based on communication between the governing and governed and building consensus. Dryzek (2002) supported the development of opportunities which enable the consensus, dialogue, and communication between actors in the decision-making processes by conveying communicative rationality into political decisionmaking processes. Forester (1992) was one of the theorists, who developed the communicative planning approach by conveying the communicative or collaborative rationality -that is used instead of each other in the literatureinto planning. According to Forester (1992), communication between participants/actors during planning process is very crucial for communicative planning. Therefore, planning activities in the communicative logic necessitate communication, common-sense, compromise and cooperation.

Healey (1997) who was one of the theoreticians that developed the communicative planning theoretically, based the communicative planning on the communication and deliberation processes which is open to the effects of all of the actors and in which unequal power relations are minimized in the planning process. According to Healey (1992), communicative planning approach contains the following elements:

- The planning process should include publicly open, interactive and interpretive elements. 
- Planning should include diversities and different discourses, opinions and ideas.

- Planning should contain interpersonal and intercultural respect to the diversities.

- Planning should be able to focus on the discussion forms and controversial areas in which problems, strategies, tactics, and values about the planning by the participants/actors are included.

- Planning should enable the development of different claims, forms, and policies in various areas.

- Planning should be able to improve the tools and methods that enable evaluations of participants/actors to reflect on the plans.

- Planning should be able to develop processes in which participants/actors can acquire information about the plan and other participants in the planning processes, develop relationships and assert values and approaches about the planning.

- Planning should be able to provide the opportunity of developing collaboration for participants/actors that would change the existent conditions and processes of planning.

In this context, while communicative planning develops a pluralist perspective between the participants/actors, it also urges the necessity of the bargaining processes about the planning to become deliberative, collaborative and publicly open. Therefore, it was aimed to eliminate the unequal political and economic power relations that have dominance and decisiveness in the traditional planning processes with communicative planning processes that are based on the communication of all of the actors (Fainstein, 2000; Harris, 2002; Hibbard and Lurie, 2000). For this reason, most of the supporters of communicative planning emphasized that communicative planning approach would improve the interaction, collaboration and deliberation processes of all of the actors by eliminating the traditional elitist power relations and thus, contributing significantly to producing more democratic and desirable plans (Booher and Innes, 2002; Healey, 1998).

Innes and Booher (2000) who have focused on the processes of communicative planning, stated that an approach which is based on a face-to-face dialog between the participants/actors who are interested in and curious about the outcomes of the planning is dominant in the communicative planning processes. In this context, in order for revealing the efficient and productive results of face-to-face dialog (Innes and Booher, 2000), it was stated that (1) Planning should be comprehensive, (2) The dialog should take place in an environment where the collaborators/participants can speak freely and sincerely and put forward their values and opinions freely, (3) There should be both differences and independences between the collaborator/ 
participants, (4) All of the details about planning should be included into the dialog processes without restricting and (5) It is inevitable to develop the tools and processes of collaborators that all of the collaborators are equally informed, speak equally and possess equal power and influence.

The difficulty of performing in-depth discussions on the institutionalization of communicative planning (see Ball, 1998; Hooper, 1992 for detailed information) had led theoreticians into sorting out some practical way-outs. (Allmendinger and Tewdwr-Jones, 2002). Thus, the common point of developed communicative theories, approaches, and definitions should mainly base on the planning process. For this reason, most of the discussions among the theoreticians had focused on how the communicative planning processes should apply. Therefore, implementers have become an issue that requires more caution in communicative planning theories. The implementers that are indicated in the theory have usually been "planners" (Fox-Rogers and Murphy, 2015). For this reason, the theoreticians of communicative planning focus their discussion on the role of planners (Fainstein, 2000). Therefore, communicative planning mostly focused on the development of planning processes that would guide the planners. In this context, it was emphasized that it is required and important for planners to be implementers who listen to the participants/actors on the basis of communication and equality, evaluate different opinions with sensitivity and prioritize processes that establish consensus between these opinions instead of highlighting their bureaucratic leadership that disapproves communication, dialog and consensus between the actors (Fainstein, 2000).

Thus, eluding from the traditional positions and roles of planners constitues the basis of communicative planning (Innes, 1995). It is due to the reason that planners in the communicative planning approach are considered to be the key communication tool, mediator and negotiator among related actors of the communicative planning (Forester, 1989; Healey, 1992; Innes, 1996). In this context, Innes (1998) suggests planners to perform dialog improvement practice by spending their time talking and communicating with the participants. According to Innes (1998), this practice is the most important way of improving communication that planners can be negotiators and mediators. By sharing the same opinion, Healey (1997) also suggested that being in communication with all participants by the planners would improve the adaptation and practice towards their new roles, which are included in the communicative planning logic such as being negotiator and mediator. According to Forester (1989), when planners realize the communicative nature of their occupation, they would develop practical methods and strategies that would improve this communication. Therefore, Forester (1989), as many communicative planning theoreticians, focused on the discussions that were considered helpful in guiding planners. In this context, he argued as being the most important tasks of planners (1) to develop communication and dialog with the participants, (2) to 
carefully listen to the participants, and (3) to understand in which cases, to what, how and why the participants agree on instead of their paternalistic, bureaucratic and traditional habits and roles.

In this context, communicative planning approach that criticizes the traditional roles of planners discusses planners who have equipped their professional expertise and values with communicative virtue instead of planners who are related with bureaucratic approach and values as an expert and technocrat that equipped with technical knowledge and hierarchical roles (Healey, 1992). Thus, communicative planning approach describes planners and planning processes which are based on communication apart from and beyond the procedures, norms, politics, and institutions in the traditional sense. For this reason, the planner described by the communicative planning is a person who associates professional knowledge with sophisticated knowledge, value and communication skill and have eluded from the traditional roles, processes, and norms (Healey, 1992). In this regard, a planner in the communicative planning approach is a decision-maker, organizer, strategist and negotiator who strengthens the communication between the local authority and participants/actors and makes the local authority open and sensitive to communication-based planning approach. Thus, a planner is a person who provides and sustains communication, dialog, and participation between the local authorities and actors in the planning processes (see Figure 1). As it is seen in the Figure 1, official public institutions/local authorities including planners consider to be in communication and network among all the actors of decision making such as citizens and other interest groups, related participants so as to strengthen communicative planning. Beside that it demonstrates the planners and other public officers play role of being strategist and negotiator in the ground of communication among other actors related to planning.

Figure 1: The Paradigm of Communication and Collaboration Network

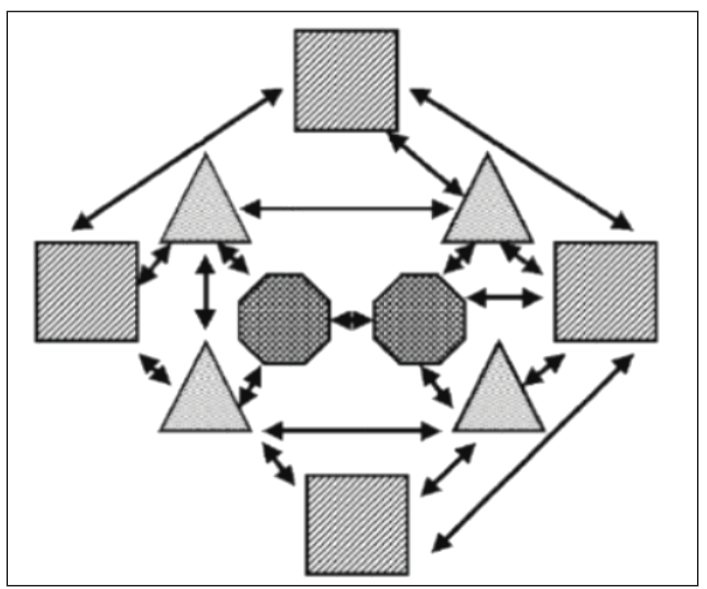

Citizen

W Public Institution/Local

Authority

$\Delta$ Other Interest Groups/Related

Participants

* The Flow of Communication

Source: (Innes and Booher,

2000:28) 
Table 1: Differences between the Traditional and Communicative Planning

\begin{tabular}{|l|l|l|}
\hline Basic logic & \multicolumn{1}{|c|}{ Traditional Planning } & \multicolumn{1}{|c|}{ Communicative Planning } \\
\hline $\begin{array}{l}\text { Hecision-making } \\
\text { relations }\end{array}$ & $\begin{array}{l}\text { Hierarchical directives, } \\
\text { legal regulations, top-down } \\
\text { bureaucratic administrative } \\
\text { regulations }\end{array}$ & $\begin{array}{l}\text { Commication is bottom-up } \\
\text { bottom-up collaboration processes }\end{array}$ \\
\hline Success Criteria & $\begin{array}{l}\text { Loyalty to hierarchical } \\
\text { and bureaucratic process, } \\
\text { institutions and processes }\end{array}$ & $\begin{array}{l}\text { Communicative practice, problem- } \\
\text { solving and determining strategies in } \\
\text { collaboration, considering the citizens }\end{array}$ \\
\hline Institutions & $\begin{array}{l}\text { Local authorities (elected } \\
\text { local representatives, } \\
\text { local councils, planning } \\
\text { commissions) }\end{array}$ & $\begin{array}{l}\text { Dialog meetings and panels, a strong } \\
\text { network between the participants, } \\
\text { deliberative agreements between the } \\
\text { actors }\end{array}$ \\
\hline Roles of planners & $\begin{array}{l}\text { Carrying out legal and } \\
\text { administrative rules and } \\
\text { processes by being loyal } \\
\text { to the hierarchical and } \\
\text { bureaucratic rules, processes } \\
\text { and procedures }\end{array}$ & $\begin{array}{l}\text { Being mediator, collaborative, } \\
\text { deliberative and organizer between } \\
\text { the local authorities and actors in the } \\
\text { planning process. }\end{array}$ \\
\hline
\end{tabular}

Source: (Danielsson et al., 2018)

\subsubsection{Communicative Planning Approach in Sweden: Mediator Planners?}

In Sweden, discussions on the planning approach based on the communication, dialog, collaboration, and consensus started in the late 1960s, however, legal and administrative arrangements on this subject were carried out since 1987 (Moote, McClaran and Chickerig, 1997; Overdevest, 2000). In this regard, The Planning and Building Act had been issued in 1987 (Boverket, 1998; 2006). However in the past decades have been great changes on the values and preconditions of planning aspect. Henceforth, the new Planning and Building Act (2010) and the Environmental Code which regulate the planning process in Sweden legislated by Riksdag (The Swedish Parliament). The Planning and Building Act has enabled regulations that would raise awareness towards the communication and dialog among the actors in the planning process. In this context, municipalities were authorized to perform legislations that would encourage communication and dialog between the participants/actors, raise awareness and increase the knowledge of citizens.

Besides of these, municipalities were held responsible to organize dialog meetings that involve all actors in the planning processes (Boverket, 2010). According to the Section 5,11a and 11b regulations of Sweden's planning act (Boverket, 
2010), local authorities were held responsible to (1) inform everyone about the plan who would be affected from the decision, (2) organize consulting meetings and the content of these meetings that would include everyone who are affected by the decision and wants to participate, (3) create an environment where all of the participants state their opinion freely during the meeting, (4) keep all of the communication channels open throughout the meeting, (5) develop processes and tools in which participants would be active and efficient about the plan. While this situation indicated that planning authorities in Sweden were influenced by the communicative planning approaches and furthermore, it also enabled a significant zone of influence for the municipalities in the planning processes since it authorizes the municipalities about all the details of the communicative planning as well (Listerborn, 2007).

Within the framework of the planning act, municipalities attempted to develop communicative dialog model on a local scale (Henecke and Khan, 2002; SKL, 2008). Although local authorities had been keen to develop dialog with actors, various discussions emerged soon that the traditional planning approach, which was based on hierarchical roles and processes could pose a threat for the development of communicative planning (Castell, 2012; Gilljam, 2006). As a result, these discussions increased the concern on the emergence of a communicative planning model that is placed within the roles and processes of the traditional planning approach (Castell, 2016).

This concern emerged as a result of adopting a narrow and restricting attitude by the political representatives and planners towards how the communicative planning would be implemented while acknowledging the importance of planning approach that is based on communication, dialog, and collaboration (Vestbro, 2012). However, certain researchers, who associated this concern with the traditional planning system of local authorities in Sweden, stated that the municipalities are not keen on radical changes that could jeopardize the traditional structure of municipalities (Castell, 2016; Tahvilzadeh, 2015; Monno and Khakee, 2012). Besides, legal regulations that were put forward in order to improve the communicative planning approach in Sweden, mostly focused on the development of participating consciousness which is one of the democratic rights of citizens and surpassed the communication dimension of communicative planning. For this reason, the most important duty of planners and local authorities have been the enhancement of participating consciousness and awareness of citizens (Listerborn, 2007).

Therefore, while local authorities in Sweden were optimistic about the communicative planning, they also make an effort to develop a planning model based on communication and dialog under the control of traditional bureaucratic processes and procedures instead of developing a communicative planning approach that is totally eluded from the traditional planning logic. Thus, they 
introduced a hybrid planning process by attempting to combine traditional planning and communicative planning (Castell, 2016).

\section{METHOD}

In the study, the semi-structured interview method was preferred for data collection method. The main reason for choosing this method is (1) to interpret the interview data appropriately, (2) to produce significant answers to the study questions, (3) to provide opportunity to measure the interview data concretely for the study questions that were determined in accordance with the aim of the study (George and Bennett, 2005). Furthermore, with the semi-structured interview technique, different questions were asked to the participants within the context of their answers apart from the pre-determined questions that were prepared in accordance with the aim and problematic of the study. Within the context of Ulleråker case, face-to-face interviews were conducted with planners who worked in the planning process of Ulleråker project in the Uppsala Municipality. A total of 13 planners were interviewed. Each interview lasted approximately 40 minutes and recorded with voice recorder. The interviews commenced in April 2018 and finalized in October 2018.

\section{RESULTS}

Ulleråker is a region located in the south of Uppsala, which is the fourth biggest city in Sweden. In this region, which is $2.5 \mathrm{~km}$ away from Uppsala city-center, around 1.800 people with middle income and mostly high education level live. Ulleråker which is one of the favorite living spaces of Uppsala due to its authentic nature and proximity to the city center was included in the urban development program of Uppsala Municipality. Within this program, a comprehensive plan was prepared which includes a total of 7.000 structures such as housing, school, sports center, closed-open parking area, and social life centers. This plan which is projected to be completed by 2030, provides living space for 15.000 people in Ulleråker. The importance of Ulleråker case is, firstly, it is a large-scale, intense and comprehensive plan which would profoundly change the current structure and nature of Uppsala, secondly, it would affect not only Ulleråker but all of the Uppsala due to its results.

In the planning process of Ulleråker, Uppsala Municipality organized 6 consultation meetings with the citizens living in the area. These consultation meetings aim to inform the citizens living in the area about the aimed plan, to answer the questions of citizens about the plan in accordance with the informing process and to take their opinions. In this context, the first meeting was held on January 2015. The first meeting was mostly informative and more than 100 citizens living in Ulleråker and surroundings participated in the meeting. The second meeting was held on April 2016. In this meeting, planners from municipality and some local politicians were exposed to intense criticisms from citizens, thus, they prepared two different 
optional (option a and option b) plan drafts by hoping the reduction in those criticisms. The third and fourth meetings that were held on May and June 2016 were conducted on the optional plans. Although the optional plan drafts were prepared to solve the "intensity" issue that was resisted by the citizens intensifely, they were still criticized by being inadequate to alleviate citizens' concern. The fifth meeting was held on August 2016. After this meeting, a new plan was created which is a hybrid of both option a and option b drafts. After the last meeting with citizens in December 2017, the Ulleråker plan was approved by the city council. In Figure 2, the Ulleråker plan approved by the Uppsala Municipality (Gray and pink sections indicate the new structures that will be constructed). It is seen in Figure 2 the blocks in the gray colors with pink numbers and lines show new buildings planned by the municipality including housing, school, sports center, closed-open parking area, and social life centers. Beside it is seen clearly how the Ulleråker region will be intensified through accepted plan. In the following titles, the results and analysis of interviews that were conducted with the planners who took part in the planning process were given on the Ulleråker case.

Figure 2: Ulleråker Plan and Ulleråker Map

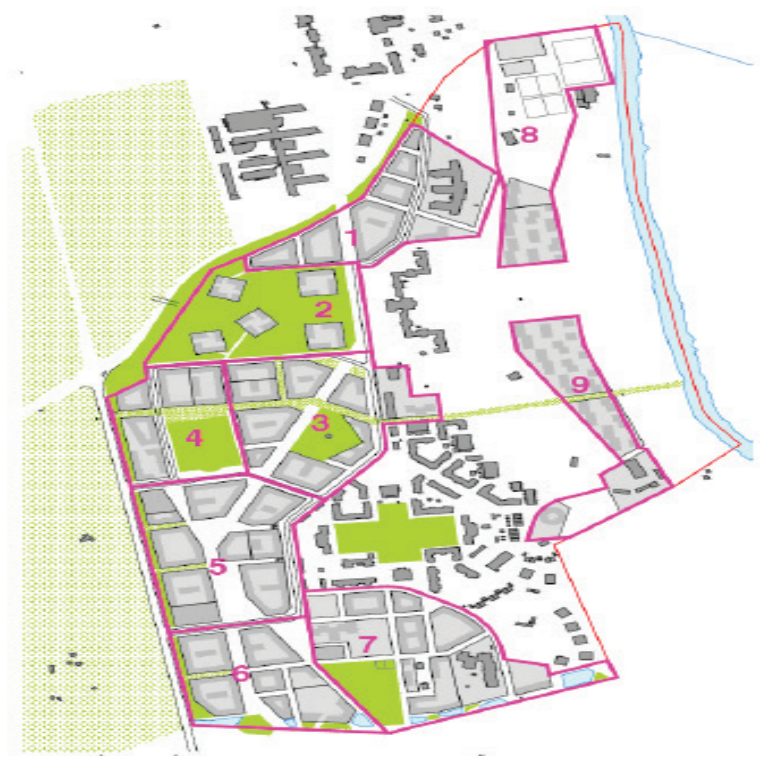

Source: (Uppsala Municipality, 2016) 


\section{DISCUSSION}

Under this section, answers will be produced to the study questions in the light of data that was obtained from the interviews. In this context:

- How do the planners perceive the roles that communicative planning attribute to them?

- How do the planners perceive application of the roles that communicative planning attributes to them?

In this section, answers were produced to study questions by creating two main titles within the context of above-mentioned study questions and sub-headings in accordance with the answers that participants gave to the interviews.

\subsubsection{How do the Planners Perceive the Roles that Communicative Planning Attribute to Them?}

Communicative planning approach criticizes planners who accept hierarchical, bureaucratic planning approach and behave under the shadow of politicians, take the expert/bureaucrat title and considered to possess technical knowledge and expertise. Communicative planning approach placed both the planning approach and planners in a more integrated position with participants/actors.

In this context, communicative planning, which is based on communication between the actors and place the planners forefront, held the planners primarily responsible in the application of communication between the actors in the planning processes. Accordingly, beyond being a passive technocrat or bureaucrat, planners are redefined as mediators and collaboratives who bring together both actors and local authorities in the dialog and deliberation processes. Therefore, the most important duty of planners seems the achievement of a feasible communicative planning both for actors and local authorities that eventually enables close communication among related actors. However, the applicability of mediator, collaborative and deliberative roles of planners in the communicative planning are closely linked to how the planners perceive their roles to be put forth by the communicative planning.

Henceforth, in Ulleråker case, although all of the interviewed planners (13) displayed a consensus on the importance of mediator and collaborative roles that communicative planning gives to them, it was revealed that they perceived these roles differently. In this context, when the answers are evaluated, 7 interviewed planners stated that they perceived the mediator and collaborative roles of planners as: (1) to raise awareness on the participation of actors to the planning, (2) to inform the actors in the planning processes, (3) to take the opinions of actors about the prepared plan and to answer their questions, (4) to organize dialog meetings with citizens that serve as consultation mechanisms, and (5) to discuss with planning authorities and political representatives of the municipality about 
the data obtained from the dialog meetings:

Our role in the planning process is closely related to being a mediator and collaborative... Because we organize informative and consultation meetings with the participants in the planning processes... We take the opinions of the participants and answer their questions in these meetings... Then, we distrubute these opinions to the related departments of municipality and the local political representatives... ${ }^{1}$

Our collaborative role defines the improvement of te level of consciousness and awareness that would increase the citizens' participation to the planning... Because, by improving that participation conscious, we also develop collaboration between the citizens and local authority... ${ }^{2}$

Communicative planning authorizes us a mediator role between the bureaucratic decision-making processes and participatory decision-making processes... We stretch the bureaucratic planning and decision-making processes with informing and consultation meetings with the participants... ${ }^{3}$

However, these perceptions of planners only include one-way communication. They only involve informing the actors, answering their questions and taking their opinions. Additionally, communicative planning discusses two-way and mutual communication. Thus, it argues planning in which actors are determiners and leaders in the planning processes and planners who can provide these conditions. Though, planners interviewed in the Ulleråker case, who had not considered themselves beneath the shadow of political representatives regarding planning processes, also were not of the opinion that they were totally apart from the guidance of political representatives.

Four interviewed planners gave answers indicating that they regarded the roles that communicative planning imposes on them to be in line with the deliberative roles and processes that depend on the two-way mutual communication, and thus, they perceive themselves as the catalysts, who could develop that communication among actors. The perception of these planners were: (1) developing a strong communication among the actors, (2) developing processes and tools that would increase the visibility and efficiency of actors in the planning processes, (3) organizing and conducting planning programs which involves as many participants as possible and in which plenty of participants can freely share their opinion, (4) developing and strengthening the mechanisms of which participants could influence the outputs of planning. Additionally, these four planners stated that communicative planning was approved and responded positively by everyone in Sweden, however, the developments that would focus the planners on the

\footnotetext{
2 interviewed planners.

3 interviewed planners.

2 interviewed planners.
} 
communication have not been completed yet:

What I perceive from the communicative planning is dialog, deliberation, participation as well as planners and local authorities, who internalized those values... We are trying to develop these in the planning processes... However, a process in line with my understanding was not established yet... ${ }^{4}$

We, the planners, should take on the responsibility to develop the planning processes that include more participatory and communicative perspective... I am trying to develop methods with my colleagues, however, not all of my colleagues make the same effort... ${ }^{5}$

I think we should extend communication beyond the one-way informing and consultation processes... Because communicative planning is based on reciprocality principle and it gives us the responsibility to develop and implement it... ${ }^{6}$

Two interviewed planners stated that they perceive the roles that communicative planning gives to them as carrying out the administrative and legal regulations and formal processes. In this context, it was deemed sufficient to become mediator and collaborator in order to implement the related regulations of the planning act that enforces information and consultation processes in the planning:

Communication in the planning processes of Sweden has long been a subject that is discussed and guaranteed with the legislations... For this reason, carrying out the legal processes emerges communicative planning and mediator planning in itself... ${ }^{7}$

The existing planning act already obliges planners and political representatives, that is, local authorities to organize informative and consultation meetings with citizens in the planning processes... The fulfilment of these regulations makes it inevitable to implement communication, and as for the planners to operate collaboratively... ${ }^{8}$

\subsubsection{How do the Planners Perceive Application of the Roles that Communicative Planning Attributes to Them?}

Almost all of the communicative planning theoreticians made statements that are focused on the planning processes and what should the planners do in these processes. As mentioned above, it was emphasized that it is inevitable to base the roles such as a negotiator, mediator, collaborative and deliberative which were put forward for planners in the communicative planning on a constant communication

\footnotetext{
1 interviewed planner.

2 interviewed planners.

1 interviewed planner.

1 interviewed planner.

1 interviewed planner.
} 
practice. This practice was considered as mandatory both for the adaptation of the planners and the motivation of participants. However, it should be emphasized that the duty of planners is not limited to the practice of communication. As it was also mentioned before, encouraging the participants to participate in the planning process, obtaining information about the participants, comprehending to what, why and how do the participants agree/disagree on, developing dialog and communication channels between the participants, moderating between the different opinions and values of participants, conducting a planning process that is open to different strategies and values and developing collaborations with participants that can change the existing conditions, processes and outputs of the planning are among the primary duties of planners.

13 interviewed planners stated that it is required to reflect communication and deliberation-based roles that communicative planning put forward to them to the planning processes in order to create a more democratic plan. Additionally, it was observed that the interviewed planners had different perspectives about the application of these roles. Hence, while 6 out of 13 interviewed planners in the Ulleråker case limited the collaboration and deliberation-based mediator, negotiator role in the planning process as the informing of participants and taking their opinions, 5 planners stated that the roles that communicative planning give to them are not applied on a communication basis and 2 planners stated that it is impossible to apply the roles that communicative planning give to them exactly to the planning processes.

6 interviewed planners thought that the dialog meetings were performed within the application of communicative planning. Thus, those 6 planners regarded that the dialog meetings were organized to inform the citizens and other participants, to answer their questions and to take their opinions into consideration about the plan, which were in line with the full scope of Swedish Planning Act. In this context, these planners mostly gave answers that are focused on informing and consultation meetings and processes. However, it should be noted that the answers of planners had included the superficial informing of participants and consulting to them about a plan already designed. Therefore, an application which is about being a mediator and deliberative by the planner both between the participants/ actors and the local authority was not mentioned as it was put forward by the communicative planning. For this reason, a passive planner profile and application was put forth instead of a planner who actively adopts efficient applications between the actors on the basis of communication. In this context, applications, which perceive themselves as mediator, collaborator and deliberator and thus, accordingly develop communicative planning processes were not put forward.

When the answers of interviewed planners are examined, it can be observed that: (1) In the planning process of Ulleråker project, a plan draft was prepared of which local political representatives and planners agree on, (2) A total of six 
informative and consultation meetings was organized with citizens and other participants/actors within the framework of the related provision of Sweden planning act which is about informing the residences and taking their opinions, (3) In these meetings, the plan was finalized by making small changes that would not remove the concerns and objectives of citizens/participants towards the plan such as changing certain main roads, decreasing the number of floors from 12 to 8 for four buildings which are located in areas where elderly people and children use mostly, (4) In these processes, instead of a planning approach based on active communication, informative and consultation-oriented dialog approach was acknowledged which carries out legal and formal rules. While this situation does not integrate with the communicative planning approach, it still indicates that planners have some lack of knowledge and experience both about communicative planning processes and their roles in those processes as well:

I believe that there is a misconceptualization in the communication that is discussed in communicative planning... Because the mediator role of planners does not mean that we should put forward the exact plans that citizens want... Informing the citizens and taking their opinions which are included in our planning acts is also communication and are parts of communicative planning. Therefore we fulfill communication, dialog and legal obligations. ${ }^{9}$

We perform the roles that communicative planning give to us in our dialog meetings with the citizens... We establish a dialog with citizens, inform them well and ask their opinions about the plan in these meetings... We try our best to minimize the things that disturb them in the plan... What more can be done... ${ }^{10}$

We organize the dialog meetings with citizens together with the local political representatives and participate in these meetings together... I believe that local politicians stand out more than us in these meetings... Politicians are more determinant and guiding in these meetings... We try to please the citizens and include more participants to the meetings and listen to them while endeavoring to carry out the legal processes... However, sometimes we don't know how to do this... Communication and deliberation in planning processes are new in Sweden. ${ }^{11}$

5 interviewed planners stated that the roles given to them by the communicative planning were not applied on a communicative basis. By this view, these planners emphasized that communication and deliberation processes among actors regarding planning were a new approach in Sweden whereas a certain process was required for acknowledgement and internalization of the communicative planning by the planners, local authorities and other actors, and eventually, they

91 interviewed planner.

102 interviewed planners.

112 interviewed planners. 
could not implement the collaborative and deliberative applications efficiently in the planning processes. Therefore, the interviewed planners emphasized these subjects: (1) Planners in Sweden have lack of knowledge and experience that would apply the communicative planning as required, (2) Both the legal planning regulations and the habits related with the traditional logic of the planning processes prevent the improvement of efficient communicative context based on communication, deliberation and dialog, (3) The perception of planners as bureaucrats and technocrats as it is in traditional context makes it difficult for planners to be independent and liberated from traditional implementations, roles and processes. Therefore, according to the interviewed planners it can be stated that they could not do away with the traditional roles and processes and could not meet the communicative planning expectation that is based on mediator, collaborative and deliberative processes between the actors in the planning processes. While, on one hand, this situation degrades the planning processes in Sweden to informative and consultation processes, on the other hand, it could not extend the planners beyond the bureaucrat identity:

I think we could not overthrow our previous habits, and for this reason, we could not develop efficient deliberation and dialog processes and applications... ${ }^{12}$

Now, we are prioritizing to fulfill the legal procedures... Why? Because we could not develop the participatory and deliberative approach and processes yet... ${ }^{13}$

Planners are not independent enough to develop collaborative or deliberative planning processes yet... Thus, we cannot behave completely independent from the political and economic concerns in the planning processes... ${ }^{14}$

2 planners stated that it was not possible to apply the roles given by communicative planning to planning processes in practice. These planners stated that strictly institutionalized representative, traditional hierarchical and bureaucratic process that is based on the well-functioning of representative democracy made it impossible to apply the communicative planning:

On the one hand, we have a representative democracy and decision-making political representatives, on the other hand, people are discussing collaborative strategy determining and decision-making... How could these two be applied at the same time?... Is it possible?... I don't think so... ${ }^{15}$

\footnotetext{
121 interviewed planner.

133 interviewed planners

142 interviewed planners.

152 interviewed planners.
} 


\section{CONCLUSION}

As known, the traditional planning were based on hierarchical and bureaucratic planning processes and planners, who carry the specialist, technocrat and bureaucrat identity. By this view, in this study, the communicative planning, which was based on communication, dialog and deliberation among actors and were developed on the criticism of the traditional planning were discussed. In this context, the mediator, collaborative and deliberative roles of planners that were established through the communicative planning logic were also interrogated. Communicative planning, which criticizes the traditional planners and hierarchical planning processes due to reasons such as not putting forward efficient and democratic results, is based on communication, dialog, and deliberation. Hence, communicative planning, which focuses on planning processes, focused on the developing communication, dialog and participation in the planning processes through planners undertook new roles such as being mediator and negotiator. Thus, in this study, it was aimed to reveal how the planners perceive the roles that communicative planning gives to them and how do they perceive the application these roles in the Sweden Ulleråker case.

Accordingly, within the context of mediator, collaborative and deliberative roles that communicative planning gives to the planners, by this view, it is observed that:

- 9 out of 13 interviewed planners gave responses which indicate that they perceive the communicative planning as (1) One-way communication which includes informative and consultation tools, (2) Carrying out the legal and formal processes, (3) Not being completely independent and separate from the traditional and bureaucratic roles and processes.

- The other 4 planners gave responses indicating that they perceive the communicative planning as a (1) two-way communication based on dialog and deliberation among actors and beyond the one-way informing and consultation activities, (2) catalytic that would improve the communicative and deliberative processes by including maximum number of participants, (3) developer of tools with which participants could affect the planning processes and their outputs.

Accordingly, it is possible to emerge the following two key-results related with the Ulleråker case:

(1) In the Ulleråker case, the common perception among the planners is that the mediator, collaborative and deliberative planner roles which were put forward by the communicative planning are limited with one-way informative and consultation processes, they could not elude and become independent from the bureaucratic and hierarchical planning processes in which the concern of fulfilling the administrative and legal processes is predominant and traditional planning was not abandoned completely. However, it should be emphasized that the planner described by the communicative planning (as also stated by 4 
interviewed planners) is based on roles that depend on two-way communication, dialog, and deliberation. In this sense, it is important to emphasize that there is a lack of knowledge and experience among the planners in Sweden on the roles that communicative planning developed for them.

(2) Furthermore, the Ulleråker case includes important determinations in terms of revealing that there are different perceptions in the application of roles that communicative planning gives to the planners. Hence, while 6 of 13 interviewed planners in the Ulleråker case limited the collaboration and deliberation-based mediator role in the planning process as the informing of participants and taking their opinions, 5 planners stated that the roles that communicative planning give to them are not applied on a communication basis and 2 planners stated that it is impossible to apply the roles that communicative planning give to them exactly to the planning processes. In this vein, when the interview data is evaluated, it is determined that:

- There is a tendency towards passive applications, which include informative and consultation processes instead of active communication among the actors and local authority:

- There is a lack of knowledge and experience in the application of the roles put forward by the communicative planning,

- It seems difficult to create and apply the communicative planning processes through mediator, collaborative and deliberative roles of planners since traditional planning processes are not eluded.

- The existence of traditional roles and processes in the planning processes prevents the creation of an independent and liberated area, where planners apply the mediator role on the basis of communication by eluding from the hierarchical and bureaucratic applications.

In this sense, the interviewed planners underlined that communicative planning is necessary and crucial for developing better and democratic plans. However, they used expressions to show that they perceive communicative planning as a strategic method, in which existing ideas are tested and a formal process in which legal norms are fulfilled. Therefore, in the case of Ulleråker, planners have indicated that they perceive communication in planning as performing strategic and formal processes rather than developing horizontal communicative planning processes among actors. In this context, the Ulleråker case evidently demonstrated that the main priority of the some planners was to carry out the legal processes. Although the fulfillment of legal obligations was a priority, the planners interviewed have also accepted that planning and decision-making processes based on representative, hierarchical and bureaucratic way do not allow an effective communication.

Last but not the least, this study mainly revealed that planners in Sweden could 
not properly perceive the mediator, collaborative and deliberative roles given to them by the communicative planning, and thus, this prevented planners in Sweden from applying their roles efficiently. For that revelation, this study exposed some reasons such as: (1) the lack of knowledge and experience of planners in Sweden, (2) the still-existence of traditional planning roles (hierarchical and bureaucratic) and processes, (3) therefore, still-continuation of one-way communication applications among actors like informing and consulting meetings, (4) the lack of improvement about means and mechanisms that would enable two-way communication, (5) developing applications such as informing between the actors and consultation meetings instead of developing tools and methods that would improve two-way communication.

\section{PLANLAMACILARIN PRESPEKTIFINDEN ISVEÇ'TE İLTİ̧̧IMSEL PLANLAMA VE KATILIMCILIK: ULLERAKER BÖLGESİ ÖRNEĞİ}

\section{GİRIŞ}

İletişimsel anlayış, ilk olarak "iletişimsel mantık" (communicative rationality) olarak Habermas tarafından ortaya atılmış (1984); daha sonra Dryzek (1990) tarafından politika yapım süreçleri için geliştirilmiş ve Forester (1989), Sager (1994) ve Innes (1995) tarafından planlama süreçlerine adapte edilmiştir (Innes, 1996). Temel olarak iletişimsel mantık, planlama süreçlerinde katılımcılar/aktörler arası iletişim, müzakere (deliberation) ve konsensusa dayandırılmıştır. 1980’lerden itibaren ise, müzakere ve konsensüs tabanına dayanan çok sayıda planlama teorisi geliştirilmeye başlanmıştır. İngiliz literatüründe "işbirlikçi” (collaborative) planlama (Healey, 1997), Amerikan literatüründe "müzakereci” (deliberative) planlama (Forester, 1999) olarak adlandırılan "iletişimsel" (communicative) planlama, zamanla "tartışmacı" (argumentative) planlama (Fisher ve Forester, 1993), "katılımc1" (participatory) planlama (Forester, 1999) gibi benzer planlama teorilerinin de önünü açarak, kentsel planlama literatüründe baskın bir konum kazanmıştır (Allmendinger ve Tewdwr-Jones, 2002). Böylece, yaklaşık son 40 yılda çok sayıda ve çeşitli isimlerle iletişimsel planlama tanımlama ve teori yaratma sürecinden sonra, planlama süreçlerini kontrol altında tutan geleneksel, hiyerarşik ve bürokratik planlama anlayışı ve geleneksel roller yerine, sağduyuya, müzakereye, uzlaşmaya ve ortaklaşmaya dayanan yeni iletişimsel süreçler ve roller geliştirilmiştir (Mazza, 1995). Bu bağlamda, sağduyu, müzakere, uzlaşma ve ortaklaşmanın kim/kimler tarafından nasıl sağlanacağı konusu iletişimsel planlama tartışmalarının odağında yer almıştır (Rogers ve Murphy, 2014).

İletişimsel planlama anlayışında büyük oranda sorumluluk planlamacılara 
verilmiştir. Böylece, planlamacıların geleneksel bürokrat/teknokrat rollerinin ötesine geçip planlama süreçlerinde geleneksel siyasal ve elitist güç odaklarını dağıtarak, vatandaşları planlama süreçlerinde güçlü ve etkin kılma ve planlama süreçlerini müzakereci ve uzlaştırıcı bir tabana taşıma misyonu yüklenmiştir. $\mathrm{Bu}$ anlamda, planlamacıların birincil görevi sağduyulu olmak, insanları bilgilendirmek, dinlemek ve farklı görüşler arasında sosyal-ekonomik olarak güçlü ve baskın olmaya çalışan gruplara izin vermeyerek konsensüs yaratmak ve konsensusun çıktılarını plana yansıtmaktır (Fainstein, 2000).

Ancak, uygulamada planlamacıların geleneksel bürokratik rollerinden ve geleneksel planlama anlayışından ne kadar uzaklaşabildikleri ve ne kadar başarılı bir konsensus yaratabildikleri uzun zamandır tartışılagelen bir diğer konu olmuştur (Mazza, 1995). Dolayısıyla, kentsel planlama literatüründe, geleneksel rolleri değişen planlamacıların yeni rollerine odaklanan bir çok çalışma bulunmasına rağmen, planlamacıların bu yeni rollerini nasıl algıladıkları ile uyguladıklarını planlamacıların gözünden irdeleyen çalışma yok denecek kadar azdır. Dolayısıyla, bu çalışmanın ana amacı, planlamacıların iletişimsel kuramlarının kendileri için ortaya koyduğu rolleri nasıl algıladıklarını ve bunları nasıl yerine getirdiklerini onların gözünden inceleyerek ortaya koymaktır. Bu bağlamda, bu çalışmada öncelikle şu sorulara yanıt aranmıştır;

(1) Planlamacılar iletişimsel planlamanın planlamacılar için ortaya koyduğu rolleri nasıl algilamaktadırlar?

(2) Planlamacılar iletişimsel planlamanın planlamacılar için ortaya koyduğu rolleri nasıl uygulamaktadırlar?

\subsection{Literatür Özeti}

\subsection{1. İletişimsel Planlamanın Anlamı ve Planlamacıların Değişen Rolü}

Geleneksel planlama anlayışında, yerel siyasi temsilcilerin güdümündeki bürokratlar olarak bilinen planlamacılar, daha çok planlama konusunda teknik bilgi ve uzmanlık sahibi profesyoneller olarak politik ve top-down hiyerarşik sistemin tamamlayıcısı olarak görülmüşlerdir (Beckman, 1964). Geleneksel planlama mantığında planlamacılar, planlama süreçlerinde, kamu çıkarını gözetmek dışında bir çok diğer siyasi ve yönetsel unsurlar arasında bir harmoni oluşturmakla sorumlu karar verici otorite olan seçilmiş yerel temsilcilere bilgi ve uzmanlığıyla yardım ve destek sunma rolünü yürütmüşlerdir (Beckman, 1964). Dolayısıyla, geleneksel planlama anlayışında planlamacılar, seçilmiş temsilcilerin yönlendirmesi ve politik kaygılarını içeren hiyerarşik ve bürokratik planlama süreçleri içinde tanımlanmışlardır. İletişimsel planlama mantığı ise, geleneksel planlama anlayışının bahsedilen hiyerarşik ve bürokratik mantığının ötesinde, katılımcılar/aktörler arası iletişim ve etkileşim üzerine oturtulmuştur.

İletişimsel mantık, ilk olarak Habermas (1984) tarafından bürokratik roller ve 
yasal yönetsel düzenlemelerle yöneten-yönetilen arasında eşitsiz güç ilişkileri ortaya koyan sistemin eleştirisi olarak işlenmiştir. Habermas’ın ortaya koyduğu temel iletişimsel mantık, yöneten ve yönetilen arasında iletişim ve konsensüs geliştirmeye dayandırılmıştır. Dryzek (2002) ise, bu iletişimsel mantığı siyasal karar alma süreçlerine taşıyarak karar alma süreçlerinde konsensüs, diyalog ve aktörler arası iletişime imkan tanıyan fırsatların geliştirilmesini savunmuştur. Forester (1992), iletişimsel (communicative) ya da literatürde birbiri yerine kullanılan işbirlikçi (collobarative) mantığı planlamaya taşıyarak, iletişimsel planlama anlayışını geliştiren teorisyenlerde biri olmuştur. Forester'e (1992) göre planlama sürecinde, katılımcılarla/aktörlerle iletişim iletişimsel planlama için hayati öneme sahiptir. Bu nedenle, iletişimsel mantıkta planlama aktiviteleri, iletişim, sağduyu, uzlaşma, işbirliği gerektirmektedir.

\subsection{2. İsveç’te İletişimsel Planlama Anlayışı: Arabulucu Planlamacılar?}

İsveç’te katılımcılar/aktörler arası iletişim, diyalog, işbirliği ve konsesusa dayalı planlama anlayışı tartışmaları 1960'larda başlamış; ancak, bu konuda yasal ve yönetsel düzenlemeler 1987 yılından itibaren yapılabilmiştir (Overdevest, 2000). Nitekim 1990’larda Boverket (İsveç İskan ve Planlama Ulusal KomitesiThe Swedish National Board of Housing and Planning) tarafindan yapilan yeni planlama yasası (Planning and Building Act) ile (Boverket, 1998; 2006; 2010), planlama süreçlerinde aktörler arasında iletişim, diyalog ve işbirliğine yönelik farkındalığı geliştirecek düzenlemelere yer verilmiştir. Bu bağlamda belediyelere, katılımcılar/aktörler arası iletişim ve diyaloğu özendirecek, vatandaşların bilgi ve farkındalığını arttıracak yönde düzenlemeler yapma yetkisi tanınmış; ayrıca, planlama süreçlerinde tüm aktörleri kapsayan diyalog toplantıları düzenleme sorumluluğu verilmiştir (Boverket, 2010).

İsveç'te yerel yönetimler, iletişimsel planlamaya pozitif yaklaşmakla birlikte, geleneksel planlama mantığından bütünüyle sıyrılmış bir iletişimsel planlama anlayışı geliştirmek yerine, top-down bürokratik işleyiş ve süreçlerin kontrolünde diyalog ve müzakere anlayışına dayalı bir planlama modeli geliştirme çabası sarf etmiştir. Bu nedenle, geleneksel planlama mantığı ile iletişimsel planlama mantığını birleştirmeye çalışarak melez bir planlama anlayışı ortaya çıkarmışlardır (Castell, 2016). Bu şekilde de, geleneksel planlama mantığının kontrolünde ve geleneksel planlama mantığına tamamen aykırı olmaksızın kendine yer edinmeye çalışan iletişimsel planlama anlayışı, basit biçimde danışma niteliğindeki diyalog toplantılarına/süreçlerine indirgenmiştir (Moote, McClaran ve Chickerig, 1997). 


\section{YÖNTEM}

Bu çalışmada İsveç’in dördüncü büyük kenti olan Uppsala'da bulunan Ulleråker bölgesine ilişkin Ulleråker kentsel planlama projesi incelenmiştir. Bu bağlamda veri toplama yöntemi olarak yarı yapılandırılmış mülakat yöntemi tercih edilmiştir. $\mathrm{Bu}$ yöntemin tercih edilmesinin temel sebebi, çalışmanın amacı doğrultusunda belirlenen araştırma sorularına; (1) Mülakat verilerinin amacına uygun biçimde yorumlanabilmesi, (2) Araştırma sorularına anlamlı cevaplar üretilebilmesi, (3) Mülakat verilerinin somut biçimde ölçülebilmesine imkan tanımaktadır (George ve Bennett, 2005). Ayrıca, yarı-yapılandırılmış mülakat tekniği sayesinde çalışmanın amacı ve problematiği doğrultusunda önceden hazırlanmış sorular dışında, katılımcıların verdikleri cevaplar bağlamında katılımcılara farklı sorular da yönlendirilebilmiştir. Ulleråker örneği kapsamında, Uppsala Belediyesi’nde Ulleråker projesinin planlama süreçlerinde çalışmış planlamacılarla yüz-yüze mülakatlar yapılmıştır. Toplamda 13 planlamacıyla görüşülmüştür. Her mülakat ortalama 40 dakika sürmüş ve ses kaydediciyle kaydedilmiştir.

\section{TARTIŞMA}

İletişimsel planlama anlayışı, hem geleneksel hiyerarşik, bürokratik planlama anlayışını hem de bu hiyerarşik süreçlerde siyasetçilerin, diğer deyişle siyasal temsilcilerin gölgesinde hareket eden, uzman bürokrat sıfatlarını alan ve teknik bilgi ve uzmanlığa sahip olduğu kabul edilen planlamacıları eleştirmektedir. Bu geleneksel planlama mantığı ve planlamacı figürünün demokratik ve arzu edilen sonuçlar ortaya koyamayacağını iddia eden iletişimsel planlama anlayışı, hem planlama anlayışını hem de planlamacıları katılımcılar/aktörlerle daha iç içe bir konuma yerleştirmiştir.

Bu bağlamda, planlamacıları öne çıkaran ve aktörler arası iletişimselliğe dayanan iletişimsel planlama mantığı, planlama süreçlerinde aktörler arası iletişimselliğin uygulanmasında planlamacıları birinci derece sorumlu tutmuştur. Bu doğrultuda planlamacılar planlama süreçlerinde pasif bir teknokrat ya da bürokrat olmanın ötesinde, hem aktörleri hem yerel yönetimleri diyalog, müzakere süreçlerinde buluşturan bir arabulucu bir işbirlikçi olarak yeniden tanımlanmıştır. Dolayısıyla, planlamacıların en önemli görevi, aktörler arası sıkı iletişimselliğe dayandırılmış iletişimsel planlamayı hem aktörler hem yerel yönetimler için uygulanabilir hale getirmektir. Ancak, planlamacıların iletişimsel planlamada belirtilen bu arabulucu, işbirlikçi, müzakereci rollerinin uygulanabilir bir hale gelmesi planlamacıların iletişimsel planlamanın planlamacılar için ortaya koyduğu rolü nasıl algıladıklarıyla yakından ilgilidir.

Nitekim Ulleråker örneğinde, mülakat yapılan tüm (13) planlamacılar, verdikleri cevaplarda iletişimsel planlamanın planlamacılara verdiği arabuluculuk ve işbirlikçilik rollerinin önemi konusunda fikir birliği içinde olduklarını göstermelerine rağmen, bu rolleri farklı algıladıklarını da ortaya koymuşlardır. Bu 
bağlamda, verilen cevaplar genel çerçevede değerlendirildiğinde, mülakat yapılan 7 planlamacı, planlamacıların arabulucu ve işbirlikçi rollerini; (1) aktörlerin özellikle vatandaşların planlamaya katılımı konusunda bilinç ve farkındalık yaratmak, (2) Aktörlerin, özellikle vatandaşların planlama süreçlerinde bilgilendirilmesi, (3) Aktörlerin ve yine özellikle vatandaşların hazırlanan plana ilişkin görüşlerinin alınması ve sorularının cevaplanması, (4) Vatandaşlarla danışma niteliğinde olan diyalog toplantıları düzenlenmesi, (5) Diyalog toplantılarından elde edilen verilerin belediyenin ilgili planlama otoriteleri ve siyasal temsilcileriyle görüşülmesi olarak algıladıklarını ifade eden cevaplar vermişlerdir.

Ancak, planlamacıların ortaya koydukları bu algı tek yönlü iletişimi içermektedir. Zira aktörlerin bilgilendirilmesi, sorularının cevaplanması ve görüşlerinin alınmasını kapsamaktadır. Bununla birlikte, iletişimsel planlama iki yönlü ve karşılıklı bir iletişimsellikten bahsetmektedir. Dolayısıyla, aktörlerin planlama süreçlerinde belirleyici ve yönlendirici olduğu bir planlamadan ve bunu sağlayabilecek planlamacılardan bahsetmektedir. Buna rağmen, Ulleråker örneğinde mülakat yapılan planlamacılar, planlama süreçlerinde bir planlamacı olarak kendilerini siyasal temsilcilerin gölgesi altında görmemekle birlikte, bütünüyle onların yönlendirmesi dışında olduklarını düşünmemektedir.

\section{SONUÇ}

$\mathrm{Bu}$ çalışmada, hiyerarşik ve bürokratik planlama süreçleri ve bu süreçlerde uzman, teknokrat ve bürokrat kimliği taşıyan planlamacılara dayanan geleneksel planlama mantığının eleştirisi üzerinden yükselen ve aktörler arası iletişimselliğe, diyaloğa ve müzakereye dayanan iletişimsel planlama mantı̆̆ ve bu mantığın planlamacilara verdiği arabulucu, işbirlikçi ve müzakereci rolleri ele alınmıştır. Geleneksel planlamacıları ve hiyerarşik planlama süreçlerini verimli, etkin ve demokratik sonuçlar ortaya çıkaramayacağı gerekçesiyle eleştiren iletişimsel planlama mantığı aktörler arası sıkı iletişimsellik, diyalog ve müzakereye dayandırılmıştır. Nitekim planlama süreçlerine odaklanan iletişimsel planlama, katılımcıların bilgilendirilmesi, danışma, diyalog ve katılım süreçlerinin geliştirilmesine odaklanmış ve bu süreçlerin pratik biçimde uygulanmasından planlamacıları sorumlu tutmuştur. Bu bağlamda, planlamacılara arabulucu ve müzakereci gibi roller yüklenmiştir. Dolayısıyla bu çalışmada, İsveç Ulleråker örneği üzerinden planlamacıların iletişimsel planlamanın kendilerine verdiği rolleri nasıl algıladıkları ve bunu nasıl uyguladıkları ortaya konulmaya çalışılmıştır. Mülakat yapılan 13 planlamacıdan 6'si planlama sürecindeki arabuluculuk, işbirliği, müzakereci rollerini katılımcıların bilgilendirilmesi ve görüşlerinin alınması uygulamalarıyla sınırlı tutarken, 5 planlamacı iletişimsel planlamanın kendilerine verdiği rollerin iletişimsel bir tabanda gereği gibi uygulanamadığını, 2 planlamacı ise iletişimsel planlamanın kendilerine verdiği rollerin pratik hayatta planlama süreçlerine aynen uygulamanın mümkün olmadığını ifade etmişlerdir. Bu bağlamda, mülakat verileri değerlendirildiğinde; 
(1) Aktörler ve yerel yönetim arasında aktif bir iletişimsellikten ziyade, bilgilendirme ve danışma süreçlerini kapsayan pasif uygulamalara yönelim olduğu,

(2) İletişimsel planlamanın ortaya koyduğu rollerin uygulanmasında bilgi ve deneyim eksiliği olduğu,

(3) Uygulamada iletişimsel planlamanın önemsendiği, fakat geleneksel planlama mantığında belirleyici ve yönlendirici olan siyasal temsilcilerin, hiyerarşik ve bürokratik süreçlerin bu pozisyonunu koruduğu,

(4) Geleneksel planlama süreçlerinden kopamamışlık durumunun, planlamacıların arabulucu, işbirlikçi ve müzakereci rollerini iletişimci tabanda planlama süreçleri yaratma ve uygulamayı zorlaştırdığı,

(5) Geleneksel rol ve süreçlerin planlama süreçlerinde hissedilir olması, planlamacıların hiyerarşik ve bürokratik uygulamalardan sıyrılıp, iletişimsel tabanda arabuluculuk rolünü uygulayabilecekleri bağımsız ve özgür bir alan yaratmaya engel olduğu tespit edilmiştir. 


\section{REFERENCES}

Allmendinger, Philip; Tewdwr-Jones, Mark (2002). "The Communicative Turn in Urban Planning: Unravelling Paradigmatic, Imperialistic and Moralistic Dimensions", Space \& Polity, Vol. 6, No. 1, pp. 5-24.

Ball, Michael (1998). "Institutions in British Property Research: A Review", Urban Studies, Vol. 35, No. 9, pp. 1501-1517.

Beckman, Norman (1964). "The Planner as a Bureaucrat", Journal of the American Institute of Planners, Vol. 30, No. 4, pp. 323-327.

Booher, David E.; Innes, Judith E. (2002). "Network Power in Collaborative Planning”, Journal of Planning Education and Research, Vol. 21, No. 3, pp. 221-236.

Boverket (1998, 2006, 2010). Vem Bestämmer? Om Medborgarinflytande och Kommunal Planering (Who is in charge? About Citizens' influence and Municipal Planning), (Karlskrona, Sweden: Boverket Pubs.).

Castell, Pal (2012). "Dialogues and Citizen Initiatives in Stigmatized Urban Areas: Reflections on the Development of Participatory Planning Principles in Gothenburg", Paper presented at the IFHP 56th World Congress: Inclusive Cities in a Global World, Gothenburg, Sweden.

Castell, Pal (2016). "Institutional Framing of Citizen Initiatives: A Challenge for Advancing Public Participation in Sweden", International Planning Studies, Vol. 21, No. 4, pp. 305-316.

Danielsson, Marianne; Hertting, Nils; Klijn, Erik-Hans (2018). "Tricky for Good Reasons: Institutionalizing Local Participatory Governance in Representative Democracy", (Eds. Nils Hertting; Clarissa Kugelberg), Local Participatory Governance and Representative Democracy: Institutional Dilemmas in European Cities, (pp. 18-63), (New York and London: Routledge).

Dryzek, John S. (1990). Discursive Democracy, (Cambridge, UK: Cambridge University Press).

Dryzek, John S. (2002). Deliberative Democracy and Beyond: Liberals, Critics, Contestations, (Oxford, UK: Oxford University Press).

Fainstein, Susan S. (2000). "New Directions in Planning Theory", Urban Affairs Review, Vol. 35, No. 4, pp. 451-478.

Fischer, Frank; Forester, John (1993). The Argumentative Turn in Policy Analysis and Planning, (London: The University College London (UCL) Press).

Forester, John (1989). Planning in the Face of Power, (Berkeley, CA: University of California Press).

Forester, John (1992). "Critical Ethnography: On Field Work in a Harbemasian Way", (Eds. Mats Alvesson ve Hugh Willmott), Criticial Management Studies, (pp. 46-65), (Beverly Hills, CA: Sage Pubs.).

Forester, John (1999). The Deliberative Practitioner: Encouraging Participatory Planning Processes, (Cambridge, MA: MIT Press).

Fox-Rogers, Linda; Murphy, Enda (2015). "Self-Perceptions of the Role of the Planner", Environment and Planning B Planning and Design, Vol. 47, pp. 1-19.

George, Alexander L.; Bennett, Andrew (2005). Case Studies and Theory Development in the Social Sciences, (Cambridge, MA: MIT Press).

Gilljam, Mikael (2006). “Demokratisk samhällsplanering klämd mellan sköldar: Om avigsidirna med medborgardialog och expertinflytante (Democratic planning squashed between Shileds: On the disadvantages of citizen dialogue and expert influence”, (Eds. Gösta Blücher; Göran Graninger), Planering med nya förutsättningar: Ny lagstiftning, nya värderingar (Planning with new conditions: New legislation, new values), (pp. 25-37), (Linköping: Linköping University Interdisciplinary Studies).

Habermas, Jürgen (1984). The Theory of Communicative Action, (London: Polity Press).

Harris, Neil (2002). "Collaborative Planning: From Theoretical Foundations to Practice Forms", 
(Eds. Philip Allmendinger; Mark Tewdwr-Jones), Planning Futures: New Directions for Planning Theory, (pp. 21-43), (London: Routledge).

Healey, Patsy (1992). "A Planner's Day: Knowledge and Action in Communicative Practice", Journal of the American Planning Association, Vol. 58, No. 1, pp. 9-20.

Healey, Patsy (1997). Collaborative Planning: Shaping Places in Fragmented Societies, (London: Macmillan Press).

Healey, Patsy (1998). "Building Institutional Capacity through Collaborative Approaches to Urban Planning", Environment and Planning A, Vol. 30, pp. 1531-1546.

Henecke, Birgitta; Khan, Jamil (2002). "Medborgardeltagande i den fysiska planeringen: en demokratiteoretisk analys av lagstiftning, retorik och praktik (Citizen participation in physical planning: A democracy theoretical analysis of law, rhetorics and practices)", Working Paper in Sociology, Lund University, Lund.

Hibbard, Michael; Lurie, Susan (2000). "Saving Land but Losing Ground: Challenges to Community Planning in the Era of Participation", Journal of Planning Education and Research, Vol. 20, No. 2, pp. 187-195.

Hooper, Alan J. (1992). "The Construction of Theory: A Comment", Journal of Property Research, Vol. 9, No. 1, pp. 45-48.

Innes, Judith E. (1995). "Planning Theory's Emerging Paradigm: Communicative Action and Interactive Practice, Journal of Planning Education and Research, Vol. 14, No. 3, pp. 183-189.

Innes, Judith E. (1996). "Planning through Consensus-Building: A New View of the Comprehensive Planning Ideal”, Journal of the American Planning Association, Vol. 62, No. 4, pp. 460-472.

Innes, Judith E. (1998). "Information in Communicative Planning", Journal of the American Planning Association, Vol. 64, No. 1, pp. 52-63.

Innes, Judith E.; Booher, David E. (2000). "Planning Institutions in the Network Society: Theory for Collaborative Planning", (Eds. Willem Salet; Andreas Faludi), The Revival of Strategic Spatial Planning, (pp. 175-189), (Amsterdam, NL: Royal Amsterdam Academy of Arts and Science).

Lijphart, Arend (1999). Patterns of Democracy: Government Forms and Performances in ThirtySix Countries, (New Haven, CT: Yale University Press).

Listerborn, Carina (2007). "Who Speaks? And Who Listens? The Relationship between Planners and Women's Participation in Local Planning in a Multi-Cultural Urban Environment", GeoJournal, Vol. 70, No. 1, pp. 61-74.

Mazza, Luigi (1995). “Technical Knowledge, Practical Reason and the Planner's Responsibility”, The Town Planning Review, Vol. 66, No. 4, pp. 389-409.

Monno, Valeria; Khakee, Abdul (2012). "Tokenism or Political Activism? Some Reflections on Participatory Planning”, International Planning Studies, Vol. 17, No. 1, pp. 85-101.

Moote, Margaret A.; McClaran, Mitchel P.; Chickering, Donna K. (1997). "Theory in Practice: Applying Participatory Democracy Theory to Public Land Planning", Environmental Management, Vol. 21, No. 6, pp. 877-889.

Overdevest, Christine (2000). "Insights and Applications. Participatory Democracy, Representative Democracy and the Nature of Diffuse and Concentrated Interests: A Case Study of Public Involvement on a National Forest District", Society and Natural Resources, Vol. 13, No. 7, pp. 685-696.

Sager, Tore (1994). Communicative Planning Theory, (Aldershot, UK: Avebury).

SKL (Sveriges kommuner och landsting/ The Swedish Association of Local Authorities and Regions) (2008). Lyssna och lyssna igen: medborgardialoger i fem kommuner (Listen and Listen Again: Citizen Dialogues in Five Municipalities), (Stockholm: Sveriges kommuner och landsting). 
Tahvilzadeh, Nazem (2015). "Understanding Participatory Governanvce Arrangements in Urban Politics: Idealist and Cynical Perspectives on the Politics of Citizen Dialogues in Göteborg, Sweden", Urban Research \& Practice, Vol. 8, No. 2, pp. 238-254.

Uppsala Municipality (Uppsala Kommun) (2016). Ulleråker medborgardialog, Rapport: Möte om detaljplan för Vattentornsparken, (pp. 1-10), (Uppsala, Sverige: Uppsala Kommun).

Vestbro, Dick Urban (2012). "Citizen Participation or Representative Democracy? The Case of Stockholm, Sweden", Journal of Architectural and Planning Research, Vol. 29, No. 1, pp. 5-17.

\begin{tabular}{|l|l|l|}
\hline KATKI ORANI / & $\begin{array}{l}\text { AÇIKLAMA / } \\
\text { EXPLANATION }\end{array}$ & $\begin{array}{l}\text { KATKIDA BULUNANLAR } \\
\text { / CONTRIBUTORS }\end{array}$ \\
\hline $\begin{array}{l}\text { Fikir veya Kavram / Idea or } \\
\text { Notion }\end{array}$ & $\begin{array}{l}\text { Araştırma hipotezini veya } \\
\text { fikrini oluşturmak / Form the } \\
\text { research hypothesis or idea }\end{array}$ & Pınar AKARÇAY \\
\hline Tasarım / Design & $\begin{array}{l}\text { Yöntemi, ölçeği ve deseni } \\
\text { tasarlamak / Designing } \\
\text { method, scale and pattern }\end{array}$ & Pınar AKARÇAY \\
\hline $\begin{array}{l}\text { Veri Toplama ve İsleme } \\
\text { / Data Collecting and }\end{array}$ & $\begin{array}{l}\text { Verileri toplamak, } \\
\text { düzenlenmek ve raporlamak } \\
\text { / Collecting, organizing and } \\
\text { reporting data }\end{array}$ & Pınar AKARÇAY \\
\hline $\begin{array}{l}\text { Tartışma ve Yorum / } \\
\text { Discussion and Interpretation }\end{array}$ & $\begin{array}{l}\text { Bulguların } \\
\text { değerlendirilmesinde ve } \\
\text { sonuçlandırılmasında } \\
\text { sorumluluk almak / Taking } \\
\text { responsibility in evaluating } \\
\text { and finalizing the findings }\end{array}$ & Pınar AKARÇAY \\
\hline $\begin{array}{l}\text { Literatür Taraması / } \\
\text { Literature Review }\end{array}$ & $\begin{array}{l}\text { Çalı̧ma için gerekli } \\
\text { literatürü taramak / Review } \\
\text { the literature required for the } \\
\text { study }\end{array}$ & Pınar AKARÇAY \\
\hline
\end{tabular}

